\title{
Palaeogeographic records in sediments of karst caves in Ukrainian Carpathians
}

\author{
Bogdan RIDUSH ${ }^{1 *, 2}$ \\ ${ }^{1}$ Department of Physical Geography and Natural Management, Chernivtsi "Yurii Fed'kovych" National \\ University, str. Kotsubynskogo 2, 58012, Chernivtsi, Ukraine. \\ ${ }^{2}$ Ukrainian institute of Speleology and Karstology, prospect Vernadskogo 4, 95-007 Simferopol, \\ Ukraine
}

* Correspondence to: Bogdan Ridush, Chernivtsi "Yurii Fed'kovych" National University, str. Kotsubynskogo 2, 58012, Chernivtsi, Ukraine. E-mail: ridush@yahoo.com.

\section{GEOREVIEW}

\section{Article history}

Received: August 2012

Received in revised form:

October 2012

Accepted: November 2012

Available online: Jan. 2013

\begin{abstract}
Karst caves in the Ukrainian Carpathians are not numerous due to the limited extent of karst rocks in the region. Most known caves are concentrated in the Uhlja karst district, associated with the Marmarosh Klippen Zone. The known cavities are relics/fragments of ancient, probably Pre-Quaternary, hypogenic karst aquifer systems, partly destroyed and partly modified by infiltration and condensation water during Pleistocene. Clastic cave deposits in few caves were examined. The palaeontological records in these sediments are represented mainly by Vertebrate faunal remains: Ursus spelaeus, $U$. arctos, Panthera leo cf. spelaea, Martes martes, Meles meles, Vulpes vulpes, Felis silvestris, Rangifer tarandus, Bison priscus, Ochotona sp. Well stratified fine clastic sediments are quite rare, as well as the speleothems available for radioisotope examination.
\end{abstract}

KEY WORDS: karst, caves, Quaternary, clastic deposits, Ursus spelaeus, Ukrainian Carpathians

\section{Introduction}

Determining of the age of relief underlies the morphogenetic analysis and is one of the fundamental problems in theoretical and applied geomorphology (Vakhrushev, 2002). A number of methods, constantly updated, were developed to define the relief age. However, the relief of young mountain systems, such as the Carpathians, is quite dynamic. Because of active denudation processes, the Upper Cainozoic continental sediments of these mountain systems containing paleoenvironmental records are rapidly destroyed.

Karst topography is a specific type of relief. Therefore, to determine its age, along with the common, some special techniques were used. Cave sediments, which are accumulated inside karst massifs, are more protected from denudation processes, and they can be preserved over millions of years. For this reason the paleogeographic records from cave sediments are often the only evidence of the nature evolution in a region. 
As most of the Alpine orogens, the Carpathian Mountain Country is generally also rich in various karst manifestations. However, unlike other parts of the Carpathian Ridge, the Ukrainian Carpathians are built mostly of flysch series and the karst rocks have a very limited extent there. The latter are represented by separate limestone blocks, scattered along the south-western macro-slope of the folded structure, and as small limestone and marble islands in the Rakhiv Crystalline Massif. Despite their limited distribution, these pieces of limestone sometimes are intensely karstified and penetrated by underground cavities, both active and fossil. They create certain geomorphological diversity in generally homogeneous geomorphological structure of the Ukrainian Carpathians. In addition, the Quaternary cave sediments, preserved in some of these underground cavities, contain valuable paleogeographic records.

\section{Research history}

The earliest known written mentions of karst phenomena in the region date back in 1558. They belong to the Moscowian ambassadors who, returning from Constantinople through Transcarpathia, stopped at the Zanivsky (Uholsky) monastery. Judging from the descriptions left, they visited the sources of the Great and Little Uholka rivers, where they were showed the Karst Bridge and Molochnyi Kamin' and Chur Caves (Petrov, 1924).

The first scientific evidence of karst caves in the Ukrainian Carpathians are included in the reports of geological expeditions (Dublyanskyi, 2005), but because of the classified (secret) nature of these reports, they have remained 'buried' in the collections of these expeditions. In 1958, the karst cavities of the Uholka were visited by the zoologists V.I. Abelintsev and I.I. Kolyushev. Among the first to study these caves are the director of Uholka school A.Yu. Hutsul (in 19591960) and the local caver P. Sova (in 1963) (Dublyanskyi, 2005).

Since 1959, the Uzhhorod tourists I.V. Ptashnikova and S.S. Balakin became interested in the cave area. They discovered here a number of caves and descended into the Druzhba (Romania) Cave to a depth of $40 \mathrm{~m}$ (Dublyanskyi, 2005). In 1962, in some caves (particularly in the Pearl Cave), they found animals remains (Kolushev, 1966). In the early 1960s, speleological research was conducted by I.I. Chernysh (Chernysh 1964, 1966). In 1963 paleozoologists G.O.Bachynsky and M.A. Voinstvenskyy examined seven caves in the area (Bachynsky, Chernysh, 1965; Dublyanskyi, 2005). Geological and karst studies were conducted by the Complex Karst Expedition of the Ukrainian SSR Academy of Science, led by B.N. Ivanov, V.N. Dublyansky and Y. Shutov (Dublyanskyi, Shutov, 1968; Dublyanskyi, Lomaev, 1980; Ivanov, 1961, 1965, 1967; Dublyanskyi, 1977).

Additional paleontological research in the caves of the Viv Cliff was carried out in 1964-1965 by Department of Zoology, University of Uzhgorod (I.I. Kolyushev, Y.I. Krochko, M.Y. Klevets, A.V. Korchinsky et al.). In 1963-1965 the expedition of the Zoological Institute of the Ukrainian SSR Academy of Sciences worked at the same site (Bachynsky, 1970). In 1964 entomological survey conducted in caves by Horodkov (Kolyushev, 1966). Since the 1980th, the active and regular caving and biospeleological research in the caves of the region conducted by cavers from Uzhgorod, Mukachevo, Rahov and experts of Carpathian Biosphere Reservation (Antosyak et al., 1989; Vargovych, 19993; Vargovych, Monych, 2004, Pokyn'chereda, 1997, 1998, etc.). Newer paleofaunistic studies were conducted between 1989 and 1993 by Y.I. Krochko, O. Korchinsky, and R.S. Vargovich (Krochko, 1973). In 1972, some of the caves in the region were studied by the Transcarpathian Paleolithic expedition of the Institute of archaeology of the Ukrainian SSR 
Academy of Sciences (Gladilin, Pashkevich, 1977). In the 1980s, the author participated in a number of speleological researches in the area, and has conducted karstological and paleogeographic investigations in 2006, 2008 (Ridush, 2008, 2009, 2010), and 2012.

\section{Geological and geomorphological conditions}

According to the karst-speleological regionalisation, the research area is situated within the Carpathian Karst Country. Within its limits the Flysch-Folded and the Marmarosh karstspeleological (KS) Provinces are distinguished, which are divided into three areas and eight districts. There are three districts within the actual Carpathian KS Region: Cliff $\left(600 \mathrm{~km}^{2}\right)$, RakhivChyvchyn $\left(800 \mathrm{~km}^{2}\right)$ and Flysch-Folded $\left(15,300 \mathrm{~km}^{2}\right)$, divided by regional overlap faults (Korzhyk, Ridush, 1990).

The Marmarosh (North) and Cliff (South) tectonic zones are bordered by the Teresva and the Borzhava Rivers (Fig. 1). Cliffs of the Southern Zone are the Jurassic tectonic nappe outliers, dented into softer flysch rocks. In the Northern Zone the cliffs are built on Jurassic limestones, Triassic dolomites, and crystalline rocks associated with the front of the Marmarosh Nappe (Dublyanskyi, Shutov, 1968).

Most investigated cavities are situated within the Northern Cliff area, in the Tereblya and Teresva Rivers interfluve. Several small caves were found in the southern part of the area, in cliffs of the Termoksa and Chertizh mounts on the Little Uholka River, composed of Upper Jurassic limestones and limestone breccias (Chernysh, 1964). Within the district, karst rocks built isolated cliffs - outliers (Semenenko, 1966) consisting particularly of Triassic micaceous limestones and blue-gray marbles up to 10-15 m thick. However, most of the caverns are developed in the Upper Jurassic rocks, located mostly within two narrow parallel strips - the Northern (Marmarosh Zone) that extends from Dovge Village to the Rakhiv Massif, and the Southern (Pennine or Cliff Zone) that can be traced from Perechyn Town to the Teresva River. The cliffs of Southern Zone are built with bedded and massive, breccia-like and conglomerate-like, clean, dolomitized, siliceous, sandy or clay limestones, 5 to $50 \mathrm{~m}$ thick.

The sedimentary features of deep faults are characteristic for the Cliff Zone: contrasts in the distribution of lithofacies and thickness on both sides of the fault, which in some geological epochs increase, but decrease in others. This concerns both boundaries of the Cliff Zone (North and South), and also the border of the heterogeneous facies, which runs inside the zone. The blocky conglomerates, inherent to the submerged wing of the deep fault, are represented as sedimentary cliffs of the Marmarosh zone. Barrier reefs occur along deep faults. Such reefs, which were formed in the Upper Jurassic on cordillera, are the northern strip of cliffs, composed of coral limestone (Gofshtein, Kraevskaya, 1966).

In the area between the Great and Little Uholka the cliffs are composed of gray, sometimes pink dense fine-grained massive reefal limestones and limestone breccias of Callovian, OxfordKimmeridgian and Tithonian-Valanginian age. They are underlied by limestone conglomerates with quartz pebbles. Cleaned by the denudation processes, they appear among micaceous sandstones, aleurolites, argillites and conglomerates with granite boulders, white quartz pebbles and crystalline schists of the Soimulska Formation of Cretaceous $\left(\mathrm{Ksm}_{1-2}\right)$ at different heights above the local erosional downcutting. There are dozens of cliffs to the north of the Uglja Village. Some of them are up to 80-100 m long and 30-50 m wide, reaching to a height of 50-80 m. Some are elongated along the local watersheds of the side tributaries of the Great and the Little Uholka 
Rivers, and are cleaned almost to the foot. The others are fully covered with deposits of the Soimulska Formation and very rarely outcrop at the surface.

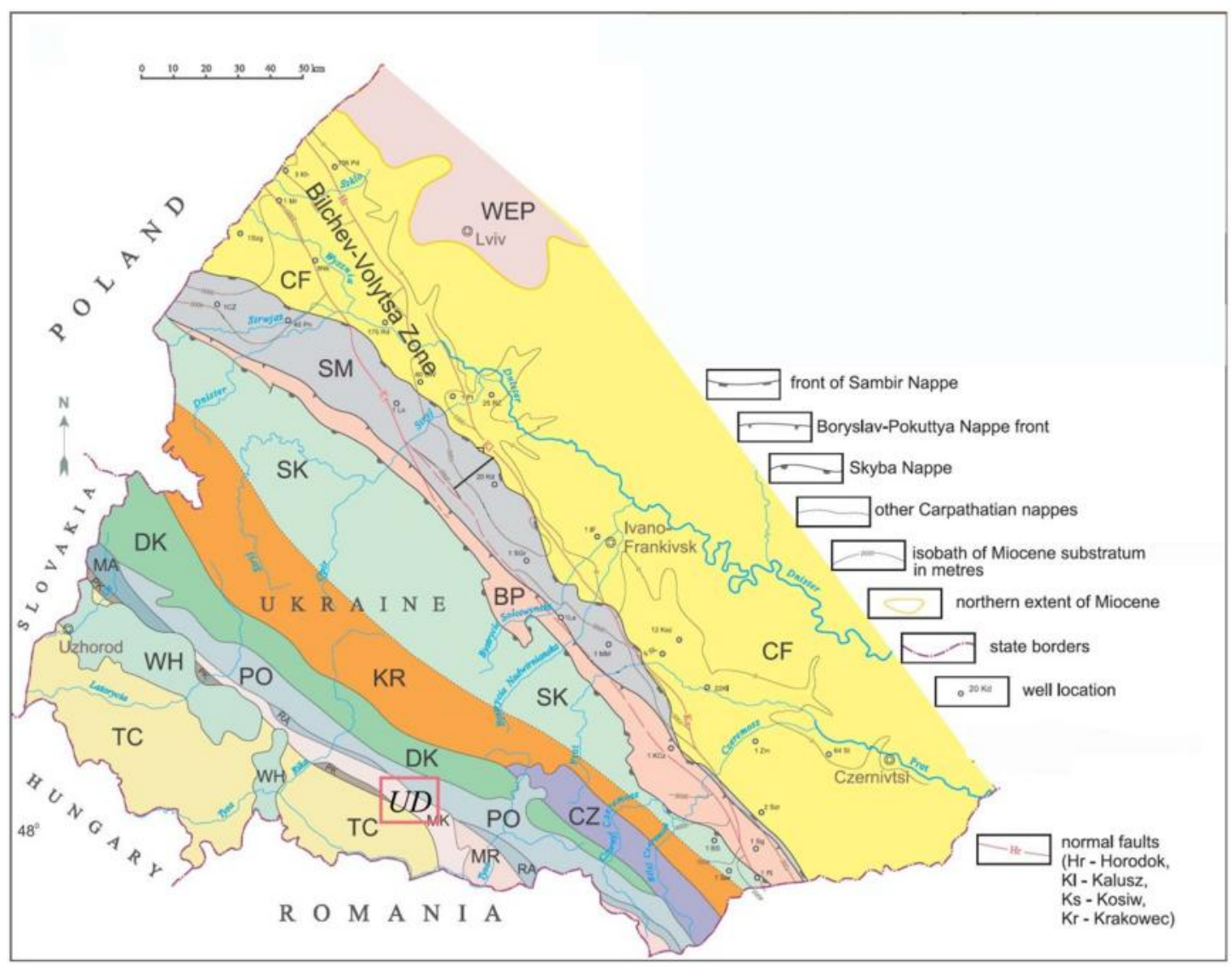

Figure 1. Tectonic map of the Ukrainian Carpathians (after Andreyeva-Grigorovich et al., 2008). Abrevations: WEP - West European Platform, CF - Carpathian Foredeep, SM - Sambir Nappe, BP Boryslav-Pokuttya Nappe, SK - Skyba/Skole Nappe, KR - Krosno Zone, DK - Dukla Nappe, CZ Chornohora Nappe, PO - Porkulec Nappe, RA - Rakhiv Nappe, MR - Marmarosh Massif, Marmarosh Klippen Zone, Ma - Magura Nappe, PKB - Pieniny Klippen Belt, WH - Vihorlat-Gutin Volcanic Massif, TC - Trans-Carpathian Depression. UD - Uholka Karst District, investigated area. This figure is available in colour online at www.georeview.ro

\section{Characteristics of caves and cave sediments}

Druzhba Cave (another name - Romania) differs from the other caves in size (total length $980 \mathrm{~m},-55 \mathrm{~m}$ depth), and by the most complex morphology and genesis. It entrance is located in the bottom of a sinkhole, in the deposits of the Soimulska Formation which cover the cliff slope. A 21 meters deep vertical pit in massive Jurassic limestones leads into a large chamber, named after I. Chernysh. The entrance pit is of the nival-corrosion origin. Apart from the pit, three subhorizontal tributaries that upstream end in impassable channels, flow into the first chamber. Starting from the blocks accumulation in the first chamber, two descending branches begin a subhorizontal gallery with a stream at the bottom, with a discharge of $0.1-2.0 \mathrm{l} / \mathrm{s}$. The gallery is of the corrosive origin and developed along tectonic faults with the stretch of $270-300^{\circ}, 340-320^{\circ}$, 
and $50-70^{\circ}$. Along the way it crosses a number of chambers in its roof, of probably hypogenic origin. In some chambers there are remains of ancient alluvial deposits, such as clay and gravel clay filling, also on the ceiling. In the Samantha Chamber particularly, the $0.5-0.7$ meter thick layer of clay-loamy sediments probably Pleistocene in age can be observed under flowstone crusts.

Some authors propose that "blocks of gray-green sericite - chlorite Paleozoic schist occur" in the cave filling (Dublyanskyi, Shutov, 1968; Dublyanskyi, Lomaev, 1980), but in fact the contact between the limestones and Paleozoic schist is exposed at the bottom of the entrance chamber and in part of the gallery. An exotic limestone block was probably included in the Cretaceous sediments, along with Paleozoic rocks.

At least two generations of flowstone formations can be distinguished in the cave. Thus, on the bottom of the Chernysh Chamber, erosion of ancient speleothems by modern watercourses was observed. At the same time modern speleothems generation occurs on the ceiling, walls and floor. V.M. Dublyansky (Dublyanskyi, Lomaev, 1980; Dubljanskij, 1977) correlated the passages of Druzhba Cave with the VIII-VII river terrace levels and estimated their age as Middle Pleistocene. In our opinion, some of the chambers in the Druzhba Cave are of Early Quaternary age, and only the vadose reworking of the main gallery, which sometimes crosses older cavities, is Late Pleistocene - Holocene.

In the cave recent fauna remains were collected. The remains are of amphibians (Salamandra salamandra, Rana sp.), predators - marten (Martes martes), badger (Meles meles), cat (Felis domestica); deer (Cervus elaphus), which accidentally fell into the vertical pit - trap (Krochko et al, 1993).

The Caves of Viv Cliff, including the Pearl Cave, White Walls Cave, Viv Cave, Lystjana Cave, and Zabuta Cave belong to a single fossil hydrogeological system. Their morphology and bedding inside the thick-layered limestone, mostly along the bedding surfaces indicate their ancient artesian genesis. We conducted trenching in the Pearl Cave and laid the excavation in the White Walls Cave.

Pearl Cave was surveyed in 2006. Upward from the entrance goes a corridor that starts with a low gallery with angled transversal profile (Fig. 2). Then we get into a rising room, one wall of which is covered with flowstone. The cavity continues downwards, but it is filled with sediments: debris, bones, rare inclusions of quartz and jade pebbles, sandstone etc. Some bones are cemented by flowstone. Fossil bones occur in debris-loamy sediments (about 20-30 cm thick). According to G.O. Bachynskyi, the cave bear (Ursus spelaeus) remains prevail in the cave, along with bones of martens (Martes martes), badgers (Meles meles), foxes (Vulpes vulpes), wild cat (Felis silvestris), reindeer (Rangifer tarandus), bison (Bison priscus) and some other small vertebrates (Bachynskyi, 1970). The later collections also attended by brown bear (Krochko et al, 1993) and pika (Ochotona sp.) (R. Vargovich, personal communication).

The top layer, which is bone-bearing, is quite dug and mixed. The roots of trees are present in the cave floor. Bones are also present in loamy sediments of the upper chamber above the flowstone. Furthermore, in our collections from the Pearl Cave burnt bone fragments were found. Since the inhabitance of the Pearls Cave is hard to imagine, the traces of human activity have to be found in the White Walls Cave, situated above.

Around 1,100 bones belonging to 18 cave bear individuals and other species were excavated during the 1960s (see (Bachynskyi, Chernysh, 1965; Tatarinov, Bachynskyi, 1968)), and now the Holocene and Pleistocene material is mixed. Therefore, the initial stratigraphy set of the site was lost. 


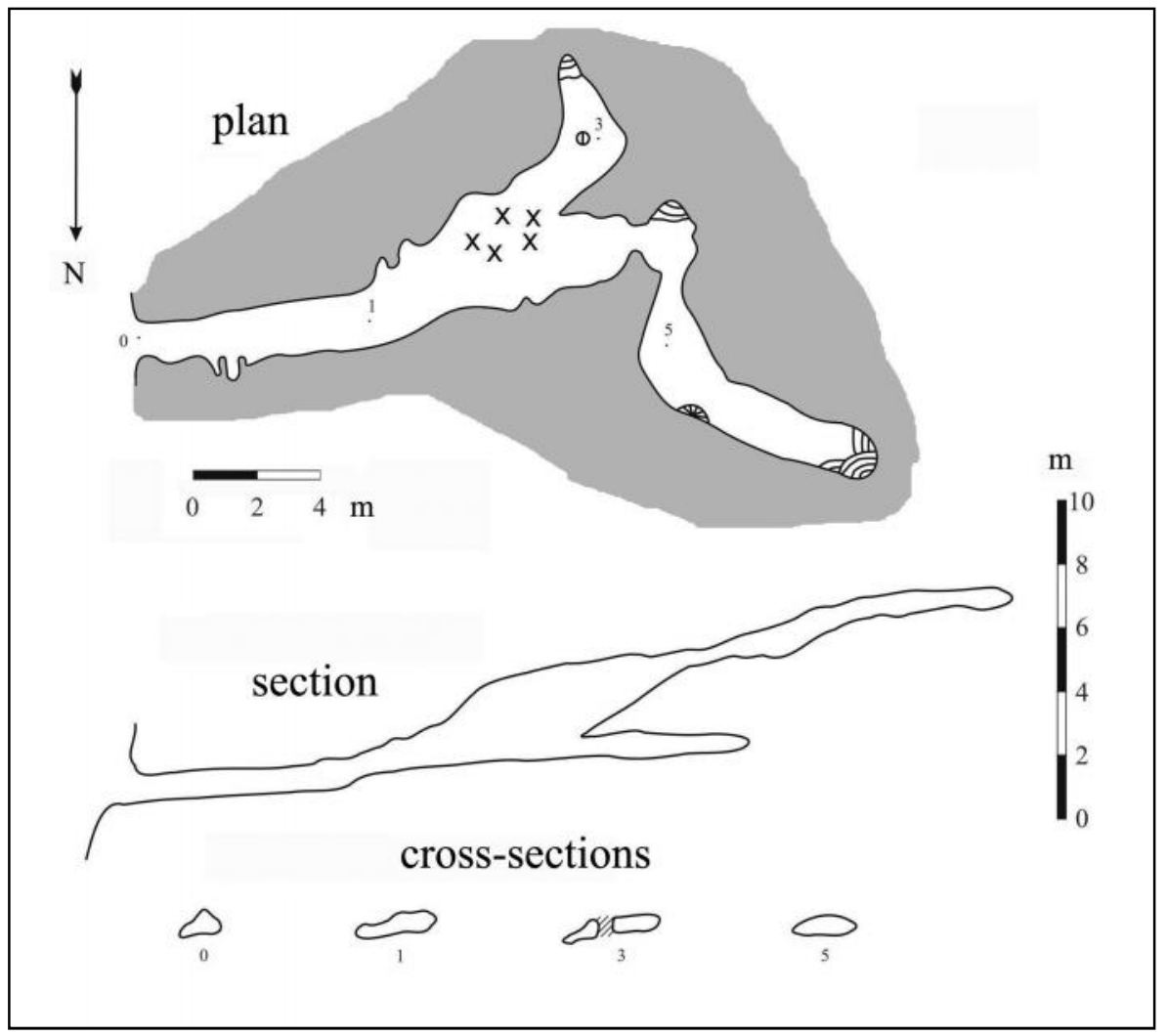

Figure 2. Plan and sections of the Perlyna Cave (survey by the "Linx" Uzhgorod caving club). $x$ - sites with faunal remains.

The White Walls Cave is located in the same Viv Cliff, a little higher than the Pearl Cave. It opens in the south side of the cliff (Fig. 2). The cavity is bedded along the bed surface. It is partially filled with secondary deposits of different genesis. Our research in this cave started in 2006.

There are five entrances to the cave. At the entrance number 3 we laid the excavation (Fig. 2). Because the floor is uneven and it rises to the North-West from the entrance, zero level was taken conventionally on the wall of the entrance portal.

The section consists of three main units:

1 - loose brown - gray loam alternating with angular gravel - $0-0.5 \mathrm{~m}$

2 - light - yellow loam, strongly carbonatic, sandy, with fragments of flowstone crust (up to 10 $15 \mathrm{~cm}$ thick), crushed stalactites and stalagmites $-0.5-0.8-1 \mathrm{~m}$;

3 - light-brown, lumpy loam, with numerous inclusions of animal bones; in the roof - flowstone crust $1-2 \mathrm{~cm}$; quartz pebbles and gravel up to $5 \%$ by volume, „rounded“ limestone pebbles and boulders up to $50 \%$.

The bone-bearing unit begins under the debris and slabs of calcite flowstone from ca. $0.8 \mathrm{~m}$ deep. There are many plant roots in sediments. Bones are poorly preserved and heavily cracked as they are located in the zone of seasonal temperature fluctuations and often penetrated with a thin tree roots. All units include pebbles of quartz, jasper and sandstone, probably originating from conglomerates of Soimul Formation. On the right side of the excavation pit, at the level of unit 2 , red lumpy loam can be observed. 
Animal remains consist mainly of teeth, skull fragments and fragments of postcranial skeletons of cave bears (Ursus spelaeus Ros.). We also found two molars and several bones of the postcranial skeleton of a large adult male of pantherine cat (Panthera leo cf. spelaea Ros.). This is the first find of this type in the region of the Ukrainian Carpathians.

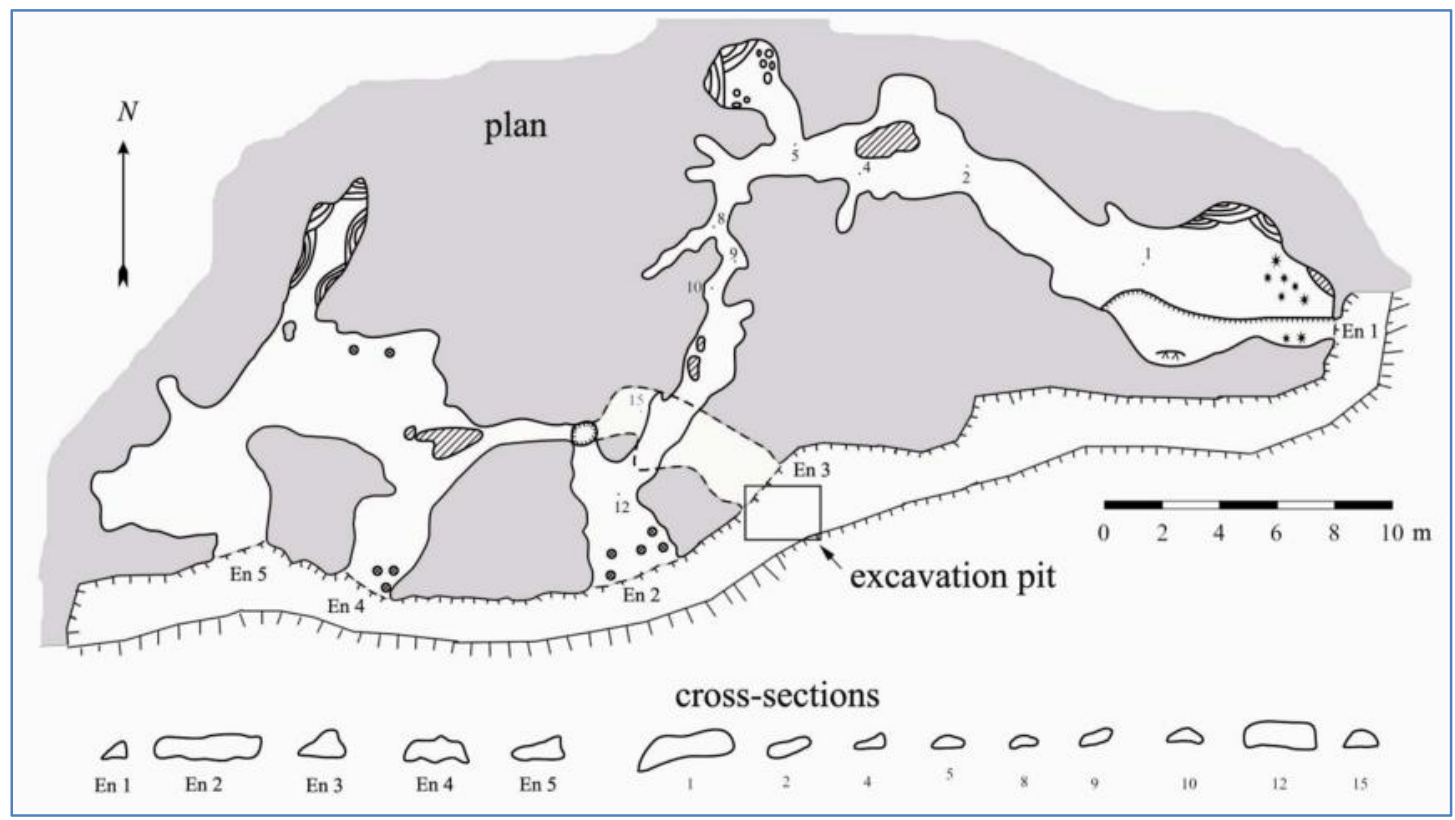

Figure 3. Plan and sections of the Bilykh Stin Cave (survey by the "Linx" Uzhgorod caving club).

Bear Fang Cave was studied in 2006. The entrance is $10 \mathrm{~m}$ wide and exposed to the north. Its floor is covered with boulders that have fallen through probably due to the cryogenic weathering, and a thick layer of fallen leaves. Next after the entrance grotto, a narrow low passage leads to a small room ( $2 \times 7 \mathrm{~m}$, and $3-4 \mathrm{~m}$ high). There is a meander-like fissure in the ceiling of transitional corridor. The bottom of the gallery is filled with loose sediment up to $1 \mathrm{~m}$ thick. The cave ends with a karst breccia filling.

Excavation pit $1 \mathrm{~m}$ deep was dug near the entrance of the gallery. It stopped on the large blocks. The sediment sequence consists of brownish loam which includes angular debris. Light-gray loam with "rounded" debris is bedded below. This layer is slightly concave downward. At 30-35 cm a 3$5 \mathrm{~cm}$ thick subhorizontal gray layer of unknown origin occurs. Bones, mostly cave bear teeth and phalanges, are found on the surface and in the upper layer $(0-5 \mathrm{~cm})$.

Chur Cave, surveyed in 2006, consists of one big room close to the top of a mountain. Its entrance is a collapse in the cave roof, $1 \mathrm{~m}$ in diameter and $3 \mathrm{~m}$ deep. A grand excavation pit, $3 \mathrm{~m}$ deep, conducted by cavers can be seen the cave. There is no trace of bones or cultural layer. The section is represented with clay-loamy bed including boulders and gravel of metamorphosed limestone, and micaceous sandstone boulders. Uphill the cave is blocked with flowstone formations.

Flat calcite boulders (calcite crust) about $10 \mathrm{~cm}$ thick lie horizontally in a loam layer about 0.5 $1.0 \mathrm{~m}$ deep. It seems that the entrance was formed relatively recently within a few hundred years because we observe practically zero accumulation of material through it. 
Karst Bridge. The literature described only one Karst Bridge, but 3 arches are present, of at least human size height and several meters wide. Their size and morphology indicate that they are the remnants of an ancient labyrinth artesian water - bearing system. V.N. Dublyanskyi and A.A Lomayev (1980) estimated the age of the highest forms, including karst bridges, as Early Pliocene - Early Pleistocene, with which we generally agree. The destruction of the roof of several large chambers probably happened already in the Late Pleistocene. In this case, the traces of inhabitance in these cavities of cave-dwelling predators and fossil man may be found under the rubble of the ceiling. In 1974, an expedition of the Institute of Archaeology of the Ukrainian SSR Academy of Science laid here the excavation pit $3 \mathrm{~m}$ deep, which did not give finds. While in 2012 , in the dump of these pit we find a deciduous tooth of cave bear.

Molochnyi Kamin' (Milk Stone) Cave. The cave has a relatively large size compared to the other caves in the region (amplitude - up to $18 \mathrm{~m}$ ). Its entrance has a southern exposure and the floor is covered with a thick flowstone (commonly loose, travertine-like).

During the archaeological survey of the cave in 1972, 25 stone tools and two fireplaces and numerous bones were found. Cave bear bones dominated the association. The radiocarbon age of the lowest layer in this cave is 25,550 $\pm 350 \mathrm{yrs}$ BP (GrN-7761) (Gladilin, Pashkevich, 1977). According to researchers, the cave served as a short-term camp for hunters on cave bear. In our opinion, it is unlikely that the bear remains related human activities. At least, no evidence of a cave bear utilisation were presented.

There are two floors in the cave. Teeth and bone fragments of the cave bear were found in the sediments of both floors.

\section{Results and discussion}

Among all surveyed caves, the clastic deposits from caves in the Viv Cliff (Bilykh Stin, Perlyna caves etc.) are of the greatest interest from the point of view of paleogeographic records, as well as Druzhba, Molochnyi Kamin', and Karst Bridge caves.

Thus, in the Druzhba Cave clastic sediments and speleothems are of greatest interest. Potential radioisotope studies of stalagmites in the Samantha Chamber and paleomagnetic analysis of clay and other sediments preserved in the calcite crust from this room can give unique information not only about the age of sediments, but also about the natural history of the region during the Pleistocene. Also, worth examining are the petrography and mineralogical composition of the sediments preserved here.

Sediments in caves from the Viv Cliff are the largely subaerial loams, with inclusions of host rock fragments, metamorphic rock pebbles, ancient speleothem fragments and bone remnants. Host rock debris are often rounded, in our opinion as a result of a chemical rounding probably due to the dissolution of limestone by phosphate solutions.

It is believed that the main sources of phosphates in cave sediments are urine, feces and other waste products of animals, and especially bat guano (Ford, Williams, 1989). T. Kul'kova and $\mathrm{V}$. Lubin believe that phosphate materials accumulated in natural shelters (dens and lairs of animals in caves) originate from remains of prey of predators, bones of animals that died of natural causes, the pellets of predatory birds, and feces. The cave strata containing the remains of cave bears (the so-called cave bear layers) are particularly rich in phosphates (Kul'kova, Lubin, 1980). In our case, the phosphate deposits analysis was not carried out. However, basing on the 
abundance of skeletal remains in the unit 3 of the Bilykh Stin Cave, it can be argued that sediments of this layer are enriched with phosphates from bones.

In the Bilykh Stin and Perlyna caves, the remains of cave bears (Ursus spelaeus Ros.) dominate. Teeth and bones of this species were also found in Grebin, Molochnyi Kamin, Prozorykh Stin, and Vedmezhe Iklo caves (Ridush, 2009). After the calcination method dating, executed in 1960th, the age of Pleistocene fossils was determined as 100 ka BP (Bachynskyi, Chernysh, 1965). According to AMS $14 \mathrm{C}$ dating, the age of cave bear fossils from the Perlyna Cave (the materials resulted from the excavations in the 1960th) is 45,7 +2,5 / -1,9 ka BP (VERA 3736), and a few other dates exceeded the capabilities of radiocarbon analysis (D. Nagel, personal communication).

The cave bear is an important component of large mammal fauna of the Late Pleistocene. Most of their remnants originate from karst regions, where large caves were used as places of hibernation. For example, in Poland cave bears remains were found in the caves of Sudetenland, Krakowsko-Częstochowska Hills, Sventokshytsky Mountains and the Carpathians (including the Tatra and Penin). Results of AMS $14 \mathrm{C}$ dating show that during the first half of Oxygen Isotope Stage 3 (OIS 3, 50-33 ka BP, or 54-37.5 ka cal. BP), when the climate was relatively stable and warm, cave bears were distributed more or less continuously from the Sudetenland to the Carpathians. Around 33 ka BP (38.5 ka cal. BP), north of the Sudeten and Carpathian cave bears probably disappeared, or at least their number decreased over the next 4-5 thousand years. In any case, cave bears did not survive through the Last Glacial Maximum (LGM) and became extinct about 26 ka BP (31 ka cal. BP) (Nadachowski et al, 2010). Overall data for Central Europe indicate that the cave bears became extinct at about $24 \mathrm{ka}(27.8 \mathrm{ka}$ cal. BP) and did not survive past the maximum cooling of the LGM. Their disappearance is associated with the decrease of its food supply, which were basically plants. No reliable data exists to prove that this species survived the Last Glacial Maximum elsewhere outside Central Europe (Pacher et al, 2009). So, today we can assume that deposits that contain non-disturbed cave bear remains cannot be younger than 2426 ka BP. Consequently, the unit 3 in the Bilykh Stin Cave could have been formed during one of the Late Pleistocene interstadials (OIS-3 or OIS-5e?).

The finds of a large pantherine cat remains (Panthera leo cf. spelaeus Ros.) are also significant. Evidence from caves in the Central Europe (Diedrich, 2009, 2009a) shows that these animals actually were not inhabitants of deep caves, as were cave bears and cave hyenas (Crocuta spelaea Ros.). As Diedrich proves, steppe lions probably resorted to hunt for hibernating bears and their cubs in caves during very severe winters. As such hunts were probably not always successful and the lions could die in fights with the adult cave bears, and thus they are the victims of these fights that are sometimes found in caves (Diedrich, 2009a). Due to not numerous remains, the exact systematic position of the pantherine from Uholka is still unclear.

The described paleofaunistic situation implies that the place of excavation was far enough inside the rocky massif during bone accumulation, at least several tens of meters from the entrance. Indeed, on one hand, the hibernation place of cave bears had to be located beyond seasonal temperature variations at the surface, but on the other hand, far enough from the entrances to protect cubs from predators. At present this place is almost on the surface, above a vertical cliff. This indicates extensive slope regression (tens or hundreds of meters) during the Late Pleistocene and the active denudation of limestone klippens during the Late Quaternary. 


\section{Conclusions}

Data from the geological structure of the area, including drilling data, indicate a tectonic and geomorphological separation of the Upper Jurassic cliffs. The present-day relief of the Uholka karst district isn't favourable for its karstification. Based on the paleogeographic analysis, V.N. Dublyansky and A.A. Lomayev concluded that cave formation in the Uholka district occurred on the capture of transit river runoff, and later modelling by the relatively poor infiltration and condensation water supply (Dublyansky, Lomayev, 1980). In our opinion, the caves of the region have a polygenetic origin. Our reconstruction of the limestone massifs indicates that during the Pliocene - Early Pleistocene, some currently isolated cliffs probably belonged to the same unit, or there were several karst massifs with an extensive karst aquifer system. According to our observations most cavities are fragments of ancient (Pre-Quaternary?) karst artesian aquifer systems that have been exposure by the Pleistocene denudation. Among other things, at some time a capture of transit river flow occurred. After their uncovering through denudation, the limestone massifs were fragmented by deep erosional downcutting and the cave fragments that survived were later modified mostly by weathering processes (desquamation) and condensation corrosion, and in some cases (Druzhba Cave) suffered minor corrosion by modern underground flows.

Due to their uniqueness in the region of the Eastern Carpathians, the caves of the Uholka massif became valuable collectors of the paleogeographic information. Their paleogeographic, paleontological and archaeological potential is not entirely disclosed. Therefore, our investigation is only preliminary and needs to be continued by comprehensive studies of cave sediments using modern methods (paleopalynological, paleomagnetic, radioisotope, TL etc). New discoveries of buried caves containing palaeoenvironmental records in the area are possible.

\section{Acknowledgements}

We are sincerely grateful to Directorate of the Carpathian Biosphere Reserve for assistance in conducting research in caves on the Reserve territory.

\section{References}

Andreyeva-Grigorovich A. S., Oszczypko N., Ślączka A., Oszczypko-Clowes M., Savitskaya N.A., Trofimovicz N. 2008. New data on the stratigraphy of the folded Miocene Zone at the front of the Ukrainian Outer Carpathians. Acta Geologica Polonica 58 (3): 325-353. Warszawa.

Antosyak V. M., Dovganych Y. E., Zakharchyshyn L. L., Chyzhmar Yu. Yu. 1989. Karst objects on the territory of Carpathian Reservation. In Problemy kompleksnogo izuchenia karsta gornykh stran. Tbilisi: Metzniereba: 21-22. (In Russian)

Bachynskyi G. O. 1970. Taphonomic Characteristic of Fossil Vertebrates Sites in Karst Caves of Ukraine. Fizychna Geografia i Geomorfologia 4: 153-159. Kyiv. (In Ukrainian) 
Bachynskyi G. O., Chernysh I. V. 1965. New Cave Site of Fossil Vertebrates in Ukrainian Carpathians. Dopovidi Akademii Nauk Ukrains'koi RSR 12: 1631-1633. Kyiv. (In Ukrainian)

Chernysh I. V. 1964. Karst caves of the Transcarpathians. In Ohoronjaimo pryrodu, Uzhgorod: 2127. (In Ukrainian)

Chernysh I. V. 1966. At Stalactite Caves of Transcarpathians. In Karpatskie Zapovedniki. Uzhgorod: Karpaty: 36-45. (In Russian)

Diedrich C. G. 2009. Steppe lion remains imported by Ice Age spotted hyenas into the Late Pleistocene Perick Caves hyena den in northern Germany. Quaternary Research 71: 361-374. http://dx.doi.org/10.1016/j.yqres.2008.12.006,

Diedrich C. 2009a. Cave bear predation by steppe lions in Central Europe - and another reason why cave bears hibernated deeply in caves. In 15th International Cave Bear Symposium, Spišska Nova Ves (17th-20-th of September 2000). Abstract book. Bratislava: 8-9. http://www.fns.uniba.sk/fileadmin/kalendar/2009/symposium/Abstract_book.pdf

Dubljanskij V. N. 1977. Kras Sovietskych Karpat. Slovensky Kras XV, Liptovsky Mikulash: 3-22.

Dublyanskyi V. N. 2005. Istoria Ukrainskoi speleologii. Perm'-Simferopol. 111 s.: il (In Russian)

Dublyanskyi V. N., Lomaev A. A. 1980. Karstovye peshchery Ukrainy. Kyiv: Naukova Dumka. 180 s.: il. (In Russian)

Dublyanskyi V. M., Shutov Y. I. 1968. Origin and hydrogeological features of deep karst caverns of the Ukrainian Carpathians. In Pryrodni umovy i resursy Ukrainskykh Karpat. Kyiv: 166-174. (In Ukrainian)

Gladilin V. N., Pashkevych G. A. 1977. Paleogeography of the Middle and Late Wurm of Transcarpathians after the Data of Investigations in the Molochnyi Kamen' Cave. In Paleoekologia Drevnego Cheloveka. Moscow: Nauka: 106-112. (In Russian)

Gofshtein I.D. 1964. Neotectonika Karpat. Kiev: Izdatelstvo AN USSR. 146 s.: il. (In Russian)

Gofshtein I. D., Kraevskaya A. L. 1966. About the structure of the Cliff Zone of Carpathians. In Tektonika Karpat. Kiev: 34-44. (In Russian)

Ivanov B. N. 1961. Latest tectonic movement and the development of karst phenomena in Ukraine. Chetvertichnyi Period 13/15: 240-249. (In Russian)

Ivanov B. N. 1965. Some regional patterns of karst development in the Carpathian area. In Materialy VI Syezda Karpato-Balkanskoi geologicheskoi assotsiatsii. Kiev: 422-431. (In Russian)

Ivanov B. N. 1967. Quaternary karst features in the mountain regions of the Carpathian-Balkan system. In Karpato-Balkanskaya Assotsiatsia: VIII Congress. Belgrade, Vol.1: 405-410. (In Russian)

Koljushev I. I. 1966. About animal kingdom of Caves. In Karpatskie Zapovedniki. Uzhgorod: Karpaty: 46-53. (In Russian)

Korzhyk V. P., Ridush B. T. 1990. Karstological and speleological division of the Ukrainian Carpathians. In: Peshchery (Caves). Perm': 51-57. (In Russian)

Krochko Yu. I. 1973. Vertebrate fauna of some caves and catacombs of the Transcarpathian Region. In Pro ohoronu pryrody Karpat. Uzhgorod: 172-174. (In Ukrainian)

Krochko Yu. I., Korchynskyi O. I., Vargovych R. S. 1993. Quaternary bone sites of Vertebrates in karst caves of Transcarpathian. In Fauna Skhidnykh Karpat. Uzhgorod: 84-85. (In Ukrainian) 
Kul'kova T. F., Lubin V. P. 1980. The results of the study of deposits of caves Kudaro I and Kudaro III by phosphate analysis. In Kudarskie peschernye paleoliticheskie stoyanki v Yugo-Osetii. Moscow: 45-49. (In Russian)

Nadachowski A., Lipecki G., Stefaniak K., Wojtal P. 2010. Radiocarbon dates on cave bear (Ursus spelaeus) and brown bear (Ursus arctos) from Late Pleistocene of Poland. Geophysical Research Abstracts. Vol. 12. EGU2010-5815, 2010. EGU General Assembly. http://meetingorganizer.copernicus.org/EGU2010/EGU2010-5815.pdf

Pacher M., Stuart A. J. 2009. Extinction chronology and palaeobilogy of the cave bear (Ursus spelaeus). Boreas. An International Journal of Quaternary Research 38: 189-206. DOI: 10.1111/j.1502-3885.2008.00071.x

Petrov A. 1924. Mineral waters and mud baths, salt and mineral wax, stalactites and geysers in Maramarosh in XVI century. Description of contemporary eyewitness. In Karpatskiy Krai. Uzhgorod: 11-13. (In Russian)

Pokyn'chereda V. 1997. Winter population of bats in underground cavities in the Carpathian Biosphere Reservation. In International aspects of the study and protection of biodiversity Carpathians: Intern. scientific-practical. conf. Rakhiv: 148-153. (In Ukrainian)

Pokyn'chereda V. 1998. Subterranean winter quarters of bats of the Carpathian Reserve. In Zagorodnjuk I. (Ed.) Evropeiska nich kazhaniv: 166-172. Kyiv. (In Ukrainian)

Ridush B. 2009. "Bear caves" in Ukraine. Slovenský Kras. Acta Carstologica Slovaca, Vol. 47. Suppl. 1: 67-84. Liptovský Slovakia. http://www.ssj.sk/pdf/ACS_47_S1/ACS_47_S107.pdf

Ridush B. 2009. Hypogene speleogenesis in sandstones formations of the Ukrainian Carpathians. Fizychna Geografia i Geomorfologia 56: 123-129. Kyiv. (In Ukrainian)

Ridush B. T. 2010. Dynamics of karst massifs of the Ukrainian Carpathians according sediments rocky karst caves District. Geopolitika i ekogeodinamika regionov 1: 21-31. Simferopol. (In Ukrainian) http://science.crimea.edu/zapiski/geopolitik/tom6_1_2/6_1_2.pdf

Semenenko N.P. (Ed.) 1966. Geologia SSSR. Vol. 28. Part I. Karpaty, Geologicheskoe opisanie. Moscow. 540 s.: il. (In Russian)

Tatarinov K. A., Bachynskyi G. O. 1968. Cave Sites of Pliocene and Quaternary Vertebrates in the Western Regions of Ukraine. Bulleten' Moskovskogo Obshchestva Ispytatelei Prirody. Otdel Biologicheskij, 73 (5): 114-121. Moscow. (In Russian)

Vakhrushev B. A. 2002. Problems of age dating in karst geomorphology. Fizychna geografia $i$ geomorfologia 42: 86-93. Kyiv. (In Russian)

Vargovych R. S. 1993. To the study of the invertebrate fauna in the caves of Transcarpathia. In Fauna Skhidnykh Karpat: suchasnyi stan i ohorona. Materialy mizhnarodnoi konferentsii (Uzhgorod, 13-16 Sept. 1993): 260-263. Uzhgorod. (In Ukrainian)

Vargovych R.S., Monych O. 2004. Caves and tunnels of Transcarpathia and their fauna. In Zagorodnjuk I. (Ed.), Fauna pecher Ukrainy: 169-179. Kyiv. (In Ukrainian). 